\title{
Morphological and Morphometric Characterization of Eodinium posterovesiculatum (Ciliophora, Ophryoscolecidae) in Brazilian Cattle
}

\author{
Priscila Fregulia ${ }^{1}$ \\ https://orcid.org/0000-0002-6931-6965
}

Franciane Cedrola ${ }^{1}$

https://orcid.org/0000-0002-5170-656X

\section{Suyane Bordim ${ }^{1}$}

https://orcid.org/0000-0001-9074-3876

\section{Marta D'Agosto'}

https://orcid.org/0000-0003-3654-3528

\section{Roberto Júnio Pedroso Dias ${ }^{1^{\star}}$}

https://orcid.org/0000-0002-2404-4337

${ }^{1}$ Federal University of Juiz de Fora, ICB, Laboratory of Protozoology, Juiz de Fora, Minas Gerais, Brazil.

Received: 2018.02.07; Accepted: 2019.12.18.

*Correspondence: rjuniodias@hotmail.com; Tel.: +55-32-21023223 (R.J.P.D.)

\section{HIGHLIGHTS}

- The four morphotypes of E. posterovesiculatum are actually a single polymorphic species.

- The format of the caudal processes is the only morphological characteristic that sets them apart.

\begin{abstract}
The morphological variability of Eodinium posterovesiculatum (Ciliophora, Trichostomatia) has been interpreted in different ways: four distinct species or four morphotypes of the same species. The present study aims to perform morphological and morphometric comparative analysis of the four morphotypes found in cattle from the southeastern region of Brazil. Ruminal content samples were obtained from four Holstein $\mathrm{x}$ Gir cattle and fixed at $18.5 \%$ formalin for morphological analysis. Morphometry was performed based on individuals stained with Lugol's solution [1]. The infraciliary bands were stained using silver carbonate impregnation technique [2]. Morphological and morphometric characterizations, supported by literature, suggest that the four morphotypes of $E$. posterovesiculatum are actually a single polymorphic species due to small morphometric differences and mostly identical morphological characters, with the format of the caudal processes being the only morphological characteristic that sets them apart.
\end{abstract}

Keywords: rumen ciliates; ruminants; trichostomatids. 


\section{INTRODUCTION}

The genus Eodinium was proposed by Kofoid and Maclennan [3] to include protozoan ciliates of the family Ophryoscolecidae Stein, 1859. They lack skeletal plates, presenting two ciliary zones in the anterior region of the body, a rod-shaped macronucleus and two contractile vacuoles. The genus is currently represented by four species: Eodinium bispinosum Kleynhans and Van Hoven, 1976, Eodinium rectangulatum Kofoid and Maclennan, 1932, Eodinium polygonale (Dogiel, 1925), and Eodinium posterovesiculatum, which was initially described as Diplodinium (Anoplodinium) posterovesiculatum by Dogiel [4] and presents incongruences in its classification.

Since the establishment of the family Ophryoscolecidae, there have been controversies over which features best reflect the taxonomy of the group [3]. Many authors use the posterior extremity of the body to discriminate species, given its wide variety of forms $[3,5,6]$. However, according to Latteur $[7,8]$, such characteristics should not be used because they represent intraspecific variety in many species, so that the same species can have numerous configurations in caudal processes. The classification of Eodinium posterovesiculatum, an ophryoscolecid ciliate, is controversial due to the polymorphism in its body's posterior region. Latteur [8] classified its variations as forms belonging to the Diplodinium species, designating them Diplodinium posterovesiculatum f. posterovesiculatum; Diplodinium posterovesiculatum f. lobatum; Diplodinium posterovesiculatum f. monolobosum and Diplodinium posteriovesiculatum f. bilobosum. Kofoid and Maclennan [3], on the other hand, have classified them as four different species: Eodinium posterovesiculatum, Eodinium lobatum, Eodinium monolobosum and Eodinium bilobosum, while Ito and Imai [9] have classified them as morphotypes belonging to the Eodinium posterovesiculatum species: posterovesiculatum type, lobatum type, monolobosum type and bilobosum type, generating incongruences in the taxonomy.

This study presents the morphological and morphometric characterization of four $E$. posterovesiculatum morphotypes based on data on general morphology, morphometry and oral infraciliature.

\section{MATERIAL AND METHODS}

Samples of rumen content were obtained via ruminal fistula of four Holstein $\times$ Gir cattle (Bos primigenius taurus L. x Bos primigenius indicus L.) kept in the José Henrique Bruschi Experimental Field, Embrapa Gado de Leite research field in Coronel Pacheco city, Minas Gerais state, Southeastern Brazil. The animals were fed with a diet made of hay and increasing levels of urea. Each sample consisted of $20 \mathrm{~cm}$ of content fixed at $18.5 \%$ formalin [10]. The identification of species and morphotypes was based on the Ito and Imai's [9] redescription, since the authors presented more detail when compared to the original description. The morphometry was performed based on individuals stained with the Lugol's solution $[1,11]$ under Olympus BX51 microscope and Image-Pro Plus 6.0 software. The anatomic position of the ciliates was done as per methods of Dogiel [4] and the infraciliary bands were stained using the silver carbonate impregnation technique [12]. The term polybrachykinety denotes infraciliary bands composed of numerous, short and parallel kineties [13]. The drawing of E. posterovesiculatum in vivo was performed by free hand based on the observation from photographs taken from specimens under light camera, and the oral infraciliature and nuclear apparatus schemes were performed based on specimens stained using the silver carbonate. All drawings were made with the previous region of the ciliate oriented towards the top of the page.

\section{RESULTS}

\section{Taxonomic revision}

Following the classification proposed by Ito and Imai [9], the present study adopts the classification of these taxa as four morphotypes belonging to the E. posterovesiculatum species (posterovesiculatum type, lobatum type, monolobosum type and bilobosum type). The morphotypes present an oval, laterally compressed body; the adoral and dorsal ciliary zones are located within the same transverse plane in the anterior extremity of the body. A rod-shaped macronucleus is located on the dorsal surface of the body, flanked by two contractile vacuoles, one at the anterior extremity and the other at the posterior extremity of the macronucleus. The micronucleus is placed in a depression on the dorsal side of the macronucleus, its position being variable along the macronucleus. There are small cytoproct located at the posterior extremity of the body. The ciliates do not have skeletal plates. A very prominent, long and tubular vestibulum can be 
seen. Caudal processes are the only morphological characteristics that differentiate the morphotypes of $E$. posterovesiculatum, which agrees with the classification proposing a single species with polymorphism [9] (Figure 1).

The posterovesiculatum type does not present caudal processes (Figure 1f), while the lobatum type presents a small ventral spine (Figure 1g), the monolobosum type presents a prominent ventral spine (Figure $1 \mathrm{~h}$ ) and the bilobosum type presents two caudal processes, with the dorsal spine being slightly more than half the size of the ventral spine, and varying from a small protuberance to a relatively large, ventral and curved spine (Figure 1i). Also, independently of the diet of the host, the different morphotypes may occur in the same animal, like related by Ito and Imai [9].

\section{Infraciliature}

The adoral infraciliature of $E$. posterovesiculatum consists of a polybrachykinety (AP), a ventral polybrachykinety (VP), a dorsal polybrachykinety (DP) and four paralabial kineties (PK). The PA, in the Cshape and the previous part of the VP, surround the circumference of the vestibular opening, the VP extends into the vestibulum along its right wall, covering the vestibulum surface until near the posterior third of the macronucleus, DP is short. The right side of the AP is wider than the left side. The lateral kineties of the VP are arranged at an angle turned to the ventral side, while the kineties present on the central axis of the VP are randomly arranged. A row of fringings kineties (FK) surrounds the VP and goes beyond the VP in the posterior region, gradually entering the previous part of the VP. The PK, which range from four to five, are located near the right portion of the AP (Figure $1 \mathrm{~b}-\mathrm{e}$ ).
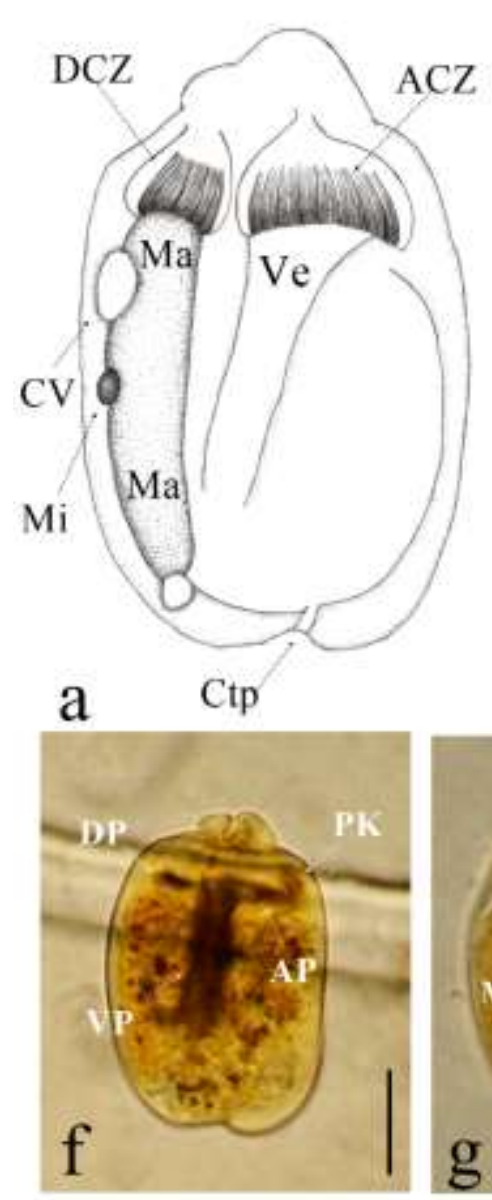
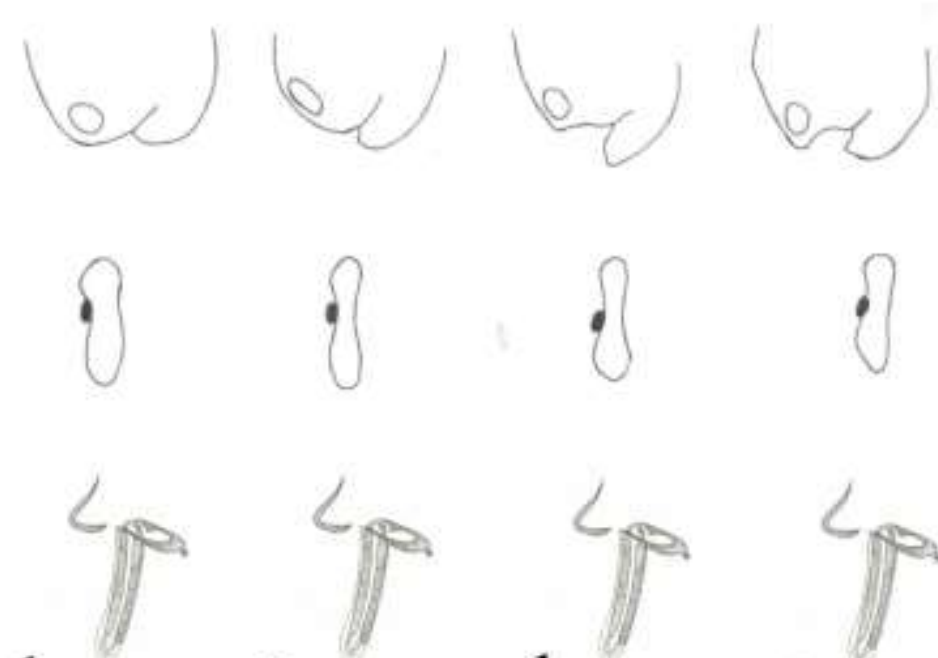

b

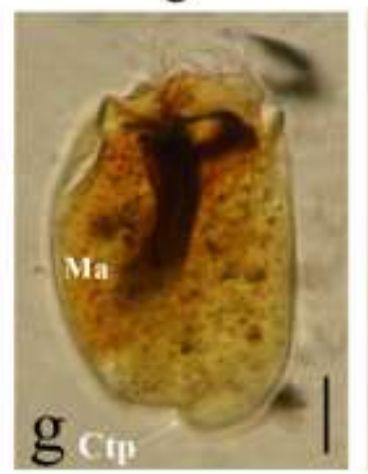

$\mathrm{c}$
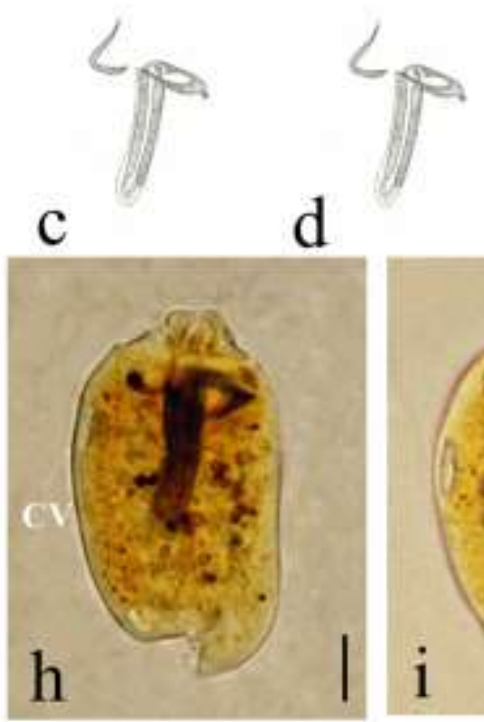

d

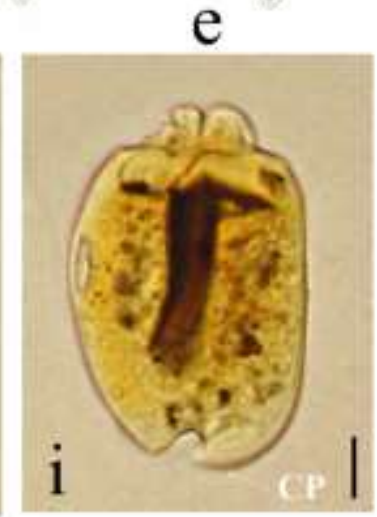

Figure 1. Four morphotypes of Eodinium posterovesiculatum (Dogiel, 1927) recorded in Brazilian cattle. (a) schematic drawing of the bilobosum type in vivo; (b) schematic drawing of the caudal process, nuclear aparatus and infraciliary of the posterovesilatum type; (c) schematic drawing of the caudal process, nuclear aparatus and infraciliary of the lobatum type; (d) schematic drawing of the caudal process, nuclear aparatus and infraciliary of the monolobosum type; (e) 
schematic drawing of the caudal process, nuclear aparatus and infraciliary of the bilobosum type. (b, f). posterovesilatum type; (c, g) lobatum type; $(\mathbf{d}, \mathbf{h})$ monolobosum type; $(\mathbf{e}, \mathbf{i})$ bilobosum type; $(\mathbf{f}-\mathbf{i})$. specimens stained with the Lugol's solution. Ma: macronucleus; Mi: micronucleus; CP: caudal projection; AP: adoral polybrachykinety; DP: dorsal polybrachykinety; PV: vestibular polybrachykinety; CV: contractile vacuole; Ve: vestibulum; AZI: adoral zone infraciliary; DZC: dorsal zone infraciliary; Bar: $20 \mu \mathrm{m}$.

Table 1. Morphometric characterization (in $\mu \mathrm{m}$ ) of four morphotypes of Eodinium posterovesiculatum (Dogiel, 1297) recorded in Brazilian cattle.

\begin{tabular}{ccccc}
\hline & $\begin{array}{c}\text { posterovesiculatum } \\
\text { type }\end{array}$ & $\begin{array}{c}\text { lobatum } \\
\text { type }\end{array}$ & $\begin{array}{c}\text { monolobosum } \\
\text { type }\end{array}$ & $\begin{array}{c}\text { bilobosum } \\
\text { type }\end{array}$ \\
\hline Body length & $64.25 \pm 8.57$ & $72.37 \pm 7.32$ & $76.06 \pm 5.35$ & $80.98 \pm 9.92$ \\
& $(54.48-77.35)$ & $(56.91-85.5)$ & $(68.97-87.89)$ & $(68.5-92.94)$ \\
Body width & $45.21 \pm 5.28$ & $49.07 \pm 4.75$ & $51.77 \pm 4.77$ & $55.13 \pm 4.38$ \\
& $(39.07-51.64)$ & $(43.52-62.76)$ & $(44.83-63.16)$ & $(45.99-62.79)$ \\
Macronuclear length & $28.59 \pm 9.19$ & $42.07 \pm 9.52$ & $45.28 \pm 7.86$ & $51.84 \pm 8.80$ \\
& $(20.03-39.81)$ & $(33.11-66.76)$ & $(34.85-59.48)$ & $(36,67-67.44)$ \\
Macronuclear width & $9.62 \pm 0.82$ & $10.88 \pm 1.89$ & $9.92 \pm 0.84$ & $10.93 \pm 0.80$ \\
& $(8.62-10.05)$ & $(7.83-15.69)$ & $(8.26-11.45)$ & $(9.54-12.35)$ \\
Micronucleus diameter & $2.77 \pm 0.48$ & $3.21 \pm 0.57$ & $3.60 \pm 0.78$ & $3.59 \pm 1.07$ \\
Micronucleus distance to the & $(2.24-3.48)$ & $(2.48-4.4)$ & $(1.68-4.81)$ & $(1.56-5.72)$ \\
anterior end of the & $12.95 \pm 5.09$ & $19.26 \pm 6.46$ & $19.93 \pm 7.12$ & $25.84 \pm 6.90$ \\
macronucleus & $(5.23-18.71)$ & $(10.87-35.46)$ & $(7.64-31.83)$ & $(7.84-41.06)$ \\
Body length / width body & $1.42 \pm 0.15$ & $1.47 \pm 0.12$ & $1.47 \pm 0.12$ & $1.47 \pm 0.10$ \\
Macronuclear length/ Body & $(1.24-1.58)$ & $(1.25-1.78)$ & $(1.24-1.65)$ & $(1.24-1.64)$ \\
length & $0.63 \pm 0.14$ & $0.85 \pm 0.16$ & $0.87 \pm 0.13$ & $0.93 \pm 0.12$ \\
Macronuclear length/ & $(0.47-0.77)$ & $(0.66-1.24)$ & $(0.65-1.15)$ & $(0.70-1.17)$ \\
Macronuclear width & $2.93 \pm 0.73$ & $3.93 \pm 0.94$ & $4.61 \pm 1.03$ & $4.75 \pm 0.78$ \\
\hline $\mathrm{N}$ & $(2.17-3.80)$ & $(2.71-6.03)$ & $(3.14-6.75)$ & $(3.18-6.11)$ \\
\hline
\end{tabular}

*Morphometry for individuals stained by Lugol's solution. posterovesiculatum type is presented in smaller number than the others due to being less abundant in the samples.

\section{DISCUSSION}

Dogiel [4] has established four subgenera belonging to the genus Diplodinium: Anoplodinium, Ostracodinium, Eudiplodinium and Polyplastron. Kofoid and Maclennan [3] promoted these to genus level, and the Anoplodinium genus was considered synonymy of Diplodinium, being thus divided in two other genera (Diplodinium and Eodinium) based on the following differences: 1) Eodinium presents the ovoid body and laterally compressed, while the body of Diplodinium is truncated and laterally compressed; 2) Eodinium macronucleus is rectilinear while, the Diplodinium macronucleus is rod-shaped with the anterior third enlarged, and 3) Diplodinium species present larger body dimensions when compared to Eodinium.

Eodinium posterovesiculatum was described as Diplodinium (Anoplodinium) posterovesiculatum by Dogiel [4], presenting three forms: f. posterovesiculatum, f. monolobosum and f. bilobosum. Later, Kofoid and Maclennan [3], in a taxonomic revision of the family Ophryoscolecidae, elevated the three forms of $D$. (Anoplodinium) posterovesiculatum to the species category and created a new genus to include them, Eodinium. Its species were named Eodinium posterovesiculatum, Eodinium monolobosum and Eodinium bilobosum, and a new species, Eodinium lobatum, was described for the genus. After some time, Latteur [8] disregarded the genus Eodinium and classified Eodinium posterovesiculatum in the genus Diplodinium. The author noticed the occurrence of polymorphism in this species and classified it in four forms: Diplodinium posterovesiculatum f. posterovesiculatum; Diplodinium posterovesiculatum f. lobatum; Diplodinium posterovesiculatum f. monolobosum and Diplodinium posteriovesiculatum f. bilobosum. Years later, Ito and Imai [9] contested the proposal, since the only difference between these ciliates is in the number of caudal processes. However, the authors did not accept the ideas of Dogiel [4] and Latteur [8] in classifying them as "forms", as the different morphotypes of E. posterovesiculatum are not geographically separated. Thus, the authors named them: posterovesiculatum type, lobatum type, monolobosum type and bilobosum type. 
In this study, we have adopted the classification proposed by Ito and Imai [9]. Although the rules of the $4^{\text {th }}$ edition of The International Code of Zoological Nomenclature (ICZN) [14] stablish that these forms must be considered subspecies, we have chosen to designate them as morphotypes, since according to Ito and Imai [9], forms not separated geographically must be classified as morphotypes and not as subspecies. Besides, due to the fact that the great part of the classification of the Ophryoscolecidae family is based on those criteria, we emphasize the possible need for a future reorganization of the family.

The morphological and morphometric description performed in the current study suggests that the four morphotypes of $E$. posterovesiculatum are probably a single polymorphic species, as suggested by Latteur [8] and Ito and Imai [9], since ciliates differ very little in morphometry (Table 1) and most of their morphological characteristics is identical. Furthermore, morphotypes differ only in the caudal processes, and it could be observed in that study that many specimens show intermediate caudal processes between the four forms.

Despite the similarities between its infraciliature with those of ciliates belonging to the Entodinium type and the Diplodinium type, E. posterovesiculatum has some unique characteristics such as the AP and the previous part of the VP that surround the entire vestibulum, oral infraciliary bands that surround the whole oral opening, which are not found in other ophryoscolecids but can be seen in ciliates belonging to the family Cycloposthiidae. These, however, do not have infraciliary bands inside the vestibulum. Moreover, the short DP and the PK located near the right portion of the AP are also not observed in any other ophryoscolecids ciliates.

The four morphotypes of $E$. posterovesiculatum characterized in this study have a morphometry similar to that of the specimens analyzed by Ito and Imai [9]. However, they differ from those found by Rossi [15] as the author describes ciliates with smaller body dimensions. There is no clear explanation for these variations, but they may be related to host geographic factors or factors inherent to the host and their management, as proposed by Goçmen [16] and Kofoid and Christenson [17].

The polymorphism in ophryoscolecid ciliates has been poorly reported and investigated. According to Martinele and D'Agosto [18], this phenomenon may be related to the interaction between ciliates, especially for relations of predation and cannibalism. When the environment in which the ciliates meet becomes competitive, they tend to modify their morphology so as to become less susceptible to being preyed upon or cannibalized. Williams and Coleman [19] observed monoclonal cultures of Diplodinium pentacanthum (Dogiel, 1927) where spines became gradually smaller, tending to disappear, suggesting that the configuration of the caudal spines is determined by environmental factors. Likewise, Williams and Coleman [19] observed that the caudal spines of Entodinium caudatum (Stein, 1858) were lost when individuals of this species were placed in monoclonal cultures. However, when placed in crops along with its main predator, Entodinium bursa (Stein, 1858), E. caudatum returned to present spines, which the authors suggested may occur in order to difficult the process of engulfment of predated species.

Diplodinium rangiferi (Dogiel was studied by Imai [20] on deer. After the slaughter, the deer's ruminal contends were collected and inoculated by an oral catheter into domestic calves that had been isolated from other animals since their birth. D. rangiferi was recorded in deer with no caudal processes. However, the specimens recorded in calves presented caudal processes ranging from a single spine to many spines, with different curvatures, which the authors believe to be linked to factors inherent to different hosts, and not related to predation by other ciliates as advocated by some authors, since the population structure remained the same.

Dehority and Potter [21], in a study on the ciliate fauna of domestic sheep, in addition to the characteristic form of Diplodinium flabellum Kofoid and Maclennan [6] observed two forms that contrasted with the original description of the species. These forms showed structural characteristics similar to those used in the original description of the species, but varied in their caudal processes, which led the authors to propose the creation of three subspecies in $D$. flabellum: $D$. flabellum flabellum, $D$. flabellum monospinatum, $D$. flabellum aspinatum. Intermediate forms were also observed, which also indicate variation among the three subspecies.

Imai [22], in a work on Entodinium ovumrajae (Dogiel, 1927) on camels, demonstrated the existence of fourteen morphotypes belonging to this species, which vary only in relation to the caudal processes and are similar in the other characteristics. The authors divided these forms into three subgroups, according to the curvature of the caudal process and it was observed that there is continuity between the shapes of these structures. The authors further argue that reporting a large number of morphotypes of $E$. ovumrajae on camels suggests that the environment provided by the camel's stomach has a strong influence on the development of this species. 
Cedrola and coauthors [23], in a study on Diplodinium anisacanthum (Cunha, 1914 ???), reported that this species is considered either polymorphic or divided into seven distinct species, although the only feature that differs from such ciliates is related to the number of caudal processes. In her study, the author found six forms belonging to this species and considered them as subspecies of $D$. anisacanthum, according to the norms of The International Code of Zoological Nomenclature (ICZN) [14] as such species were described before 1960.

Latteur $[8,24]$ states that polymorphism is common to many species of ophryoscolecid ciliates, and therefore suggests that caudal processes should not be used in the group's specific diagnosis since they reflect intraspecific variations.

According to Wright [25], regions of the small subunit of ribosomal RNA are the molecular marker most used among eukaryotes for the identification of species, as well as to elucidate their phylogeny. BaroinTourancheau [26] state that phylogeny trees based on 18S rRNA present fairly congruent data that often correspond to the taxa defined by means of morphological studies. Molecular studies using the 18S-rRNA gene $[27,28]$ indicate that the morphotypes of $E$. posterovesiculatum are grouped in a clade with high support values and have high genetic similarity $(99.9 \%)$, which suggests that they constitute the same species. This agrees with the data obtained through the morphological and morphometric characterization performed in the current study.

\section{CONCLUSION}

This study aims at a better understanding of the taxonomy of $E$. posterovesiculatum from data on its morphology and morphometry and also at discussing the polymorphism that occurs in Ophryoscolecidae and highlighting the similarity between the studied specimens, which reveals evidence of different morphotypes that constitute the same species. However, to further comprehend the state the phylogenetic relationships between such morphotypes, additional studies are required using different molecular markers and larger samples from different geographic locations and from different hosts where E. posterovesiculatum occurs, such as buffaloes and antelopes.

Acknowledgements: This work was supported by Conselho Nacional de Desenvolvimento Científico e Tecnológico (CNPq) (403336/2016-3). Conselho Nacional de Desenvolvimento Científico e Tecnológico (CNPq) provided research grant to Roberto Dias (Bolsa de Produtividade PQ), Coordenação de Aperfeiçoamento de Pessoal de Nível Superior (CAPES) to Priscila Fregulia and Fundação de Amparo à Pesquisa do Estado de Minas Gerais (FAPEMIG) to Franciane Cedrola.

\section{REFERENCES}

1. Cedrola F, Rossi M, Dias RJP, Martinele I, D'agosto M. Methods for Taxonomic Studies of Rumen Ciliates (Alveolata: Ciliophora): A Brief Review. Zool Sci. 2015 32:8-15.

2. Ito A, Imai S. Infraciliary band pattern of rumen Ophryoscolecid ciliates. Endocytobiosis Cell Res. 2006 17:103110.

3. Kofoid CA, Maclennan RF. Ciliates from Bos indicus Linn. II. The genus Diplodinium Schuberg. Univ Calif Publ Zool. 1932 37:53-152.

4. Dogiel VA. Monographie der Familie Ophryoscolecidae. Arch Protistenkd. 1927 59:1-288.

5. Kofoid CA, Maclennan RF. Ciliates from Bos indicus Linn. I. The genus Entodinium Stein. Univ Calif Publ Zool. 1930 39:471-544.

6. Kofoid CA, Maclennan RF. Ciliates from Bos indicus Linn III. Epidinium Crawley, Epiplastron gen. nov., and Ophryoscolex Stein. Univ Calif Publ Zool. 1933 39:1-34.

7. Latteur B. Diplodinium archon n. sp. Ciliate Ophryoscolecidae du rumen de l'antelope Tragelaphus scriptus Pallas. Ann Soc Belg Med Trop. 1966 46:727-740.

8. Latteur B. Revision systematique de la famille des Ophryoscolecidae Stein, 1858, sous-famille des Diplodiniinae Lubinsky, 1957, genere Diplodinium (Schuberg) sensu novo. Ann Soc R zool Belg. 1970 100:275-312.

9. Ito A, Imai, S. Ligth microscopial observation of infraciliary bands of Eodinium posterovesiculatum in comparison with Entodinium bursa and Diplodinium dentatum. J Eukaryot Microbiol. 2003 50:34-42.

10. Dehority BA. Evaluation of subsampling and fixation procedures used for counting rumen Protozoa. Appl Environ Microbiol. 1984 48:182-185. 
11. D'Agosto M, Carneiro ME. Evaluation of lugol solution used for counting rumen ciliates. Rev Bras Zool. 1999 16:725-729.

12. Rossi M, Cedrola F, Dias RJP, Martinele I, D'Agosto M. Improved silver carbonate impregnation method for rumen ciliate protozoa. Rev Bras Zool 2016 17:33-40.

13. Fernandez-Galiano D. Transfer of the widely known "spirotrich" ciliate Bursaria truncatella O.F.M. to the Vestibulifera as a separate order there, the Bursariomorphida. Trans Am Microsc Soc. 1979 98:447-454.

14. ICNZ. International Code of Zoological Nomenclature. 4th Edition. The International Trust for Zoological Nomenclature, London: 1999. 306 p.

15. Rossi, Mariana Fonseca. Taxonomia, morfologia e filogenia molecular de protistas ciliados (Ciliophora, Litostomatea) encontrados em ruminantes domésticos [master's thesis]. Juiz de Fora: Universidade Federal de Juiz de Fora, 2013, 151p.

16. Göçmen B, Rastgeldi S, Karaoğlu A, Aşkan H. Rumen ciliated protozoa of the Turkish domestic goats (Capra hircus L.) Zootaxa. 2005 1091:53-64.

17. Kofoid CA, Christenson JF. Ciliates from Bos-gaurus H. Smith. Univ Calif Publ Zool. 1933 33:471-544.

18. Martinele I, D'agosto M. Predação e canibalismo entre protozoários ciliados (Ciliophora, Entodiniomorphida, Ophryoscolecidae) no rúmen de ovinos (Ovis aries L.) Rev Bras Zool. 2008 25:451-455.

19. Williams AG, Coleman GS. The Rumen Protozoa. (New York): Springer; 1992. 450 p.

20. Imai S, Matsumoto M, Watanabe A, Sato H. Establishment of a spinated type of Diplodinium rangiferi by transfaunation of rumen ciliates of Japanese Sika Deer (Cervus nippon centralis) to the rumen of two Japanese Shorthorn Calves (Bos taurus taurus). J Eukaryot Microbiol. 2002 49:1-41.

21. Dehority BA, Potter EL. Diplodinium flabellum: occurrence and numbers in the rumen of sheep with a description of two new subspecies. J Protozool. 1974 21:686-93.

22. Imai S, Shinno T, Ike K, Morita T, Selim HM. Fourteen morphotypes of Entodinium ovumrajae (Ophryoscolecidae, Entodiniomorphida) found in the Dromedary camel of Egypt. J Eukaryot Microbiol. 2004 51:594-7.

23. Cedrola F, Dias RJP, Martinele I, D'Agosto M. Polymorphism and inconsistences in the taxonomy of Diplodinium anisacanthum da Cunha, 1914 (Ciliophora, Entodiniomorphida, Ophryoscolecidae) and taxonomic notes on the genus Diploodinium Schuberg, 1888. Zootaxa. 2017 4306:249-260.

24. Latteur B. Contribuition à la systématique de la famille Ophryoscolecidae Stein. Ann Soc R Zool Belg. 1966 96:117144.

25. Wright ADG, Tajima K, Aminov RI. Methods in Gut Microbial Ecology for ruminants. 16S/18S rDNA clone library construction and analysis. (Netherlands): Springer; 2005. 225 p.

26. Baroin-Tourancheau A, Villalobo E, Tsao N, Torres A, Pearlman RE. Protein-coding gene trees in ciliates: Comparison with rRNA-based phylogenies. Mol Phylogenet Evol. 1998 10:299-309.

27. Cedrola F, Senra MVX, D'Agosto M, Dias RJP. Phylogenetic analyses support validity of genus Eodinium (Ciliophora, Entodiniomorphida, Ophryoscolecidae). J Eukaryot Microbiol. 2017 64:242-247.

28. Cedrola F, Senra MVX, Rossi MF, Fregulia P, D'Agosto M, Dias RJP. Trichostomatid ciliates (Alveolata, Ciliophora, Trichostomatia) systematics and diversity: Past, present, and future. Front Microbiol. 202015 https://doi.org/10.3389/fmicb.2019.02967.

(0) 2020 by the authors. Submitted for possible open access publication under the terms and conditions of the Creative Commons Attribution (CC BY NC) license (https://creativecommons.org/licenses/by-nc/4.0/). 